\title{
Debt and Investment: A Firm Level Evidence
}

\author{
Fangping Peng1, Richard Cebula², Maggie Foley², Xinming Hu${ }^{3}$, Zhetan Zhang ${ }^{*}$ \\ ${ }^{1}$ Business School, Sun Yat-sen University, Guangzhou, China \\ ${ }^{2}$ Davis College of Business, Jacksonville University, Jacksonville, Florida, USA \\ ${ }^{3}$ Financial School, Guangdong University of Finance \& Economics, Guangzhou, China \\ Email: *1299535230@qq.com
}

How to cite this paper: Peng, F.P., Cebula, R., Foley, M., Hu, X.M. and Zhang, Z.T. (2018) Debt and Investment: A Firm Level Evidence. Journal of Mathematical Finance, 8, 119-126.

https://doi.org/10.4236/jmf.2018.81010

Received: May 31, 2017

Accepted: February 11, 2018

Published: February 14, 2018

Copyright (c) 2018 by authors and Scientific Research Publishing Inc. This work is licensed under the Creative Commons Attribution International License (CC BY 4.0).

http://creativecommons.org/licenses/by/4.0/

\begin{abstract}
In this study, the panel smooth transition model will be used to analyze the nonlinear relationship between debt and investment. It can be inferred from the results that debt drives investment when the debt level is relatively low. However, a rise in debt reaching the "threshold" level diminishes the chances of an increase in investments. The results above indicate: the current economic downturn being experienced will not be resolved by further leverage.
\end{abstract}

\section{Keywords}

Investment, Debt Threshold, Financial Stress

\section{Introduction}

Arguably, the first study that evaluated the connection between the financial system and macroeconomic phenomena has been attributed to Fisher (1933) [1]. The study presented in Fisher (1933) [1] introduces the debt deflation theory. To show the impact of the financial markets on the economy, Keynes (1936) [2] pointed out an insufficient demand could cause a rise in the rate of unemployment. As a progress in this line of research, "financial instability hypothesis" is developed based on Minsky (1957) [3] and then continuing with Minsky (1978 [4], 1982, [5] and 1986 [6]). It is evident from the hypothesis that the financial system can experience a transition from a level of stability to instability due to periods when the economy is thriving which can cause reckless decisions made by both the borrowers and the lenders. A continuous expression of optimism creates financial bubbles which will eventually lead to economic busts. However, it assumes that actual deposits indicate potential investment (Keen, 2013) [7]. Keen (1995) [8] revised a limited-cycle model developed in Goodwin (1967) [9] by adding the debt measure. He pointed out that debt can incur due to investors 
optimism and inequality in income and consequently, a previously stable business cycle can become a turbulent economic situation. From the microeconomic market perspective, Bernanke et al. (1999) [10] carried out a remarkable study which considers the Dynamic Stochastic General Equilibrium (DSGE) approach. However, the DSGE approach can neither explain the significant deviation of the real economy from expectations (Kocherlakota, 2000) [11], nor does it demonstrate the dynamic changes of debt (Mittnik and Semler, 2013) [12].

In recent years, the evident global financial crisis has created the need for a critical study of the connection between the financial systems and the real economy, especially as it concerns the interaction between public debt and the economy, as illustrated in de Lof and Malinen (2014) [13], Panizza and Presbitero (2014) [14], Checherita-Westphal and Rother (2012) [15], Erdil and Yetkiner (2009) [16], and Cebula (2014) [17]. However, private debt can be assumed to be as important as public debt in the studies of the role of debt in the real economy (Puente-Ajovín \& Sanso-Navarro, 2015) [18]. One area of research is prominently focused on the credit crunch experienced by troubled banks and the impact on the real economy, as shown in the studies of Adrian et al. (2010) [19], Gorton (2010) [20], and Brunnermeier and Sannikov (2014) [21]. Another line of research places emphasis on the risk premium and credit spread resulting from the changes in financial stress. From this perspective, the occurrence of excessive debt potentially causes an increase in borrowing costs, lower profit margins and investment as well as a downturn in the real economy (Proaño et al., 2014 [22]; Schleer and Semmler, 2013 [23]). These studies conclude that there is a nonlinear relationship between debt and the real economy.

Other studies, such as Hubrich and Tetlow (2015) [24], Van Roye (2014) [25], Hollo et al. (2012) [26], and Davig and Hakkio (2010) [27], yielded similar results. Hennessy et al. (2007) [28] pointed out that at the firm level, incurring an excessive debt could lead to a "drag" effect on investment.

Recently, in China, the occurrence of excessive debt and investment downturn has caused significant concerns. According to the Interest Rate Observer Journal, from 2008 to 2013, the Chinese banks' debts increased by 15.1 trillion dollars. This figure is remarkably higher than the increment in debts owed by the US banks collectively, which is an estimated 1.46 trillion dollars. Moreover, the Chinese Statistics Bureau reports that since 2012, the total investments pace for fixed assets have witnessed a steady drop. A proper comprehension of the relationship between investment and financial factors is essential to promote both the current and future activities which are important to the economy. However, due to multiple reasons, there is the absence of an established literature regarding this issue. This study seeks to fill this gap in the literature. By using the Panel Smooth Transition Model, we explore the relationship between debt and the real economy, with a particular focus on debt and investment. We further establish a dynamic relationship between debt and investment in view of exploring the diverse role of debt in investments and the real economy. We find that the exis- 
tence of low debt will have a positive impact on investment. In addition, when debt attains a specific threshold, it will have no further significant impact on increasing investment. This is identified as the main reason behind the economic slowdown experienced in China in recent years. Evidently, the "rescue efforts" made by the government was not capable of resolving the issues in the real economy which was caused by excessive debt.

The structure developed for this study is as follows: Section 2 covers the empirical analysis for this study. The final section in this report includes a summary and the suggestions regarding the considered policies.

\section{Empirical Analysis}

\subsection{Sample Selection and Data}

The sample we developed was based on the China Stock Market \& Accounting Research (CSMAR) database. We study this sample which covers a period of 2002 to 2013. Considering the specific nature of the investment in financial firms, we exclude the financial firms and firms with missing values. To prevent the influence of outliers on the results, we carry out a Winsorizing process for the maximum and minimum $1 \%$ of the variables of the sample. Table 1 indicates the methods we used to measure the variables.

\subsection{Model Estimation and Results}

Considering the theoretical analysis mentioned above showing a nonlinear relationship between variables, it is pertinent to apply a nonlinear model to analyze the relationship between debt and the real economy (investment). In this study, we use a nonlinear Panel Smooth Transition Regression (PSTR) model to explore the connection between debt and investment. The model settings are shown below:

$$
w i k b_{i t}=\alpha_{i}+\beta_{1} w i k b_{i t-1}+\beta_{2} w s k b_{i t-1}+\theta_{1} w a k_{i t-1}+\theta_{2} w_{a k} k_{i t-1} F\left(F S I_{i t-1} ; \chi, c\right)+\varepsilon_{i t}
$$

where $w i k b_{i t}$ is the dependent variable of investment rate in firm $i$ during year $t$, $\alpha_{i}$ is the firm fixed effect, $w i k b_{i t-1}$ and $w a k_{i t-1}$ represent the control variables which indicate sales growth and leverage in the firmi during year $t . F\left(F S I_{i t}: \chi, c\right)$

Table 1. Definitions and formulas of the key variables.

\begin{tabular}{|c|c|}
\hline Variable & Definition and Formulas \\
\hline & Total investment in current period $\left(I_{i t}\right) /$ Total operating income \\
\hline Investment rate & in current period $\left(Y_{i t}\right)$. \\
\hline$\left(w i k b_{i t}\right)$ & $\begin{array}{l}\text { Total investment in current period }\left(I_{i t}\right)=\text { Net fixed assets in current period } \\
\qquad\left(K_{i t}\right) \text { - Net fixed assets in last period }\left(K_{i t-1}\right)+\text { Current depreciation }\end{array}$ \\
\hline $\begin{array}{l}\text { Sales growth } \\
\qquad\left(w s k b_{i t}\right)\end{array}$ & $\begin{array}{l}\text { Total operating income in current period }\left(Y_{i t}\right)-\text { Total operating income in last } \\
\text { period }\left(Y_{i t-1}\right) / \text { Total operating income in last period }\left(Y_{i t-1}\right)\end{array}$ \\
\hline Leverage $\left(w_{a k}\right)$ & Leverage in current period $\left(L_{i t}\right) /$ Total operating income in current period $\left(Y_{i t}\right)$ \\
\hline
\end{tabular}


is a transfer function with a financial variable $F S I_{i t}$ as an observable state variable. Our measure of the financial stress is the level of debt measure developed by Mittnik \& Semmler (2013) [12], Brunnermeier \& Sannikov (2014) [21], and Proaño et al. (2014) [22]. The parameter $\chi$ determines the speed of the conversion, and $c$ represents the position parameter for the transition. Following Fouquau et al. (2008) [29], we use the following logic conversion function:

$$
F\left(F S I_{i t} ; \chi, c\right)=\frac{1}{1+\exp \left[-\chi\left(F S I_{i t}-c\right) / \delta_{z}\right]}
$$

where $\delta_{z}$ represents the standard deviation of $F S I_{i t}$ Considering that $\chi$ is a parameter which is not a free scalar and its value depends on the state variable $F S I_{i p}$ we normalize the deviation of the state parameters by dividing the standard deviation $\delta_{z}$ by the state variable $F S I_{i t}$ to explain the parameter $\chi$ directly, which involves the method used by Hakkio \& Keeton (2009) [30] to process data. Currently, the PSTR model is a linear multivariate panel regression model with variables which are in a state of continuous change. Specifically, the PSTR model gives the investment function with a heterogeneous parameter based on the parametric method because the parameters are easily interchangeable with the function of the state variable $F S I_{i t}$ For example, we define the coefficient of corporate liability level as follows:

$$
e_{i t}=\theta_{1}+\theta_{2} F\left(F S I_{i t} ; \chi, c\right)
$$

In general, if $\theta_{2}>0$, then $\theta_{1} \leq e_{i t} \leq \theta_{1}+\theta_{2}$, and if $\theta_{2}<0$, then $\theta_{1}+\theta_{2} \leq e_{i t} \leq \theta_{1}$. According to the conclusion mentioned above, the corporate has a relatively small investment rate regarding the high financial pressure (liabilities), so we expect $\theta_{2}<0$.

First, we find out the linearity of the nonlinear model test. According to Gonzalez et al. (2005) [31], we carry out the first-order Taylor expansion on $\chi=0$ for the Model (1), to obtain the following auxiliary regression model:

$$
\begin{aligned}
w i k b_{i t}= & \alpha_{1}+\beta_{1} w i k b_{i t-2}+\beta_{2} w s k b_{i t-1}+\theta_{1} w a k_{i t-1}+\theta^{\prime} w a k_{i t-1}^{2} \\
& +\theta^{\prime \prime} w a k_{i t-1}^{3}+\theta^{\prime \prime \prime} w a k_{i t-1}^{4}+\varepsilon_{i t}
\end{aligned}
$$

We use the Lagrange Multiplier (LM) test to prove whether the impact of debt on investment is asymmetric under the circumstance such as a fluctuating financial stress, as $\mathrm{H}_{0}: \theta^{\prime}=\theta^{\prime \prime}=\theta^{\prime \prime \prime}=0$. Table 2 presents the results of the impact of debt on investment. We observe that at the $5 \%$ significance level, the original hypothesis was significantly rejected. This indicates that the impact of debt on investment is non-asymmetric in the event of a fluctuating financial stress.

According to the test results stated above, we can estimate Equation (1) by PSTR model. In line with Kremer et al. (2013) [32] and Caner \& Hansen (2004) [33], first, we use the values of endogenous variables as instrumental variables to estimate transition speed parameter and get $\chi=23.847$, and the value of parameter $c$ which indicates where the transfer is and get $c=0.583$. Then, the GMM estimation method based on the dynamic panel proposed by Arellano \& Bover 
(1995) [34] provides estimation for other correlation coefficients shown in Table 3.

From Table 3, we observe that the impact of debt on investment is significantly non-linear. In periods characterized by low financial stress as experienced by the corporation, debt has a positive impact on investment $\left(\theta_{1}\right.$ is significantly greater than 0 ). While the corporate faces high debt level, the increase in debt has no significant influence on investment $\left(\theta_{1}+\theta_{2}\right.$ isn't above zero significantly). The results indicate that debt and investment have a non-linear relationship at different debt levels. However, China's debt level has no significant negative impact on investment; this is called the "financial drag effect" (Minsky, 1978 [5]; Fazzari et al., 2008 [35]). Currently, China's debt profile is almost at a level where there is a change from a positive to a negative impact of debt on investment. Furthermore, considering the current economic situation, an increase in accessibility to credit aimed at stimulating the economy has been observed to be ineffective, and it could cause a "financial drag effect". One option available to China in its bid to prevent further expansion of bank credit under expansionary monetary policy is to focus on developing the equity market rapidly in view of reducing debt.

\section{Conclusions}

The global financial crisis which began in 2007 to a large extent had the adverse effects of the financial industry on the real economy. In the case of China, understanding the influence of debt on investment can reveal useful information which can be used to prevent the Chinese economy from being affected by a risky financial market. From our analysis, it is observed that at low debt levels, there will be an increase in investments. In addition, when debt attains the threshold, the previous appreciation stimulated by debt will be eliminated.

The outcome from our studies indicates that the government needs to adopt relevant policies which can be used to prevent an experience of financial crisis. This can be achieved by putting a stop to all forms of excessive borrowing in the

Table 2. Non-linear test for the impact of debt on investment.

\begin{tabular}{cc}
\hline & $\mathrm{LM}_{\mathrm{T}}$ \\
\hline $\mathrm{H}_{0}$ & $20.514^{* * *}$
\end{tabular}

Note: ${ }^{*},{ }^{*},{ }^{* *}$ denote significance at the levels of $10 \%, 5 \% 1 \%$, respectively.

Table 3. GMM estimation results.

\begin{tabular}{cccc}
\hline Coefficient & Estimated Value & Coefficient & Estimated Value \\
\hline$\beta_{1}$ & 0.032 & $\beta_{2}$ & 0.000 \\
$\theta_{1}$ & $1.211^{* *}$ & $\theta_{2}$ & $-1.198^{* * *}$ \\
p-value & & 0.383 & \\
\hline
\end{tabular}

Note: ${ }^{*}, * * * * *$ denote significance at the levels of $10 \%, 5 \% 1 \%$, respectively. 
real economy at a time the economy is thriving.

\section{Acknowledgements}

We would like to thank the foundation from the National Natural Science Foundation of China (71673312) and Humanities and Social Sciences projects of the Ministry of Education (15YJA790079, 17YJA790058, 13YJA790033) for financial support of this research.

\section{References}

[1] Fisher, I. (1933) The Debt-Deflation Theory of Great Depressions. Econometrica: Journal of the Econometric Society, 1, 337-357. https://doi.org/10.2307/1907327

[2] Keynes, J.M. (1936) The General Theory of Employment, Interest and Money. Macmillan, London.

[3] Minsky, H.P. (1957) Monetary Systems and Accelerator Models. American Economic Review, 47, 859-883.

[4] Minsky, H.P. (1978) The Financial Instability Hypothesis: A Restatement. Thames Papers in Political Economy, Thames Polytechnic, London.

[5] Minsky, H.P. (1982) Can “It” Happen Again? M.E. Sharpe Press, New York.

[6] Minsky, H. (1986) Stabilizing an Unstable Economy. Yale University Press, New Haven, Connecticut.

[7] Keen, S. (2013) A Monetary Minsky Model of the Great Moderation and the Great Recession. Journal of Economic Behavior \& Organization, 86, 221-235.

https://doi.org/10.1016/j.jebo.2011.01.010

[8] Keen, S. (1995) Finance and Economic Breakdown: Modeling Minsky's Financial Instability Hypothesis. Journal of Post Keynesian Economics, 17, 607-635.

https://doi.org/10.1080/01603477.1995.11490053

[9] Goodwin, B.R. (1967) A Growth Cycle, in Socialism, Capitalism and Economic Growth. Feinstein, C.H., Ed., Cambridge University Press, Cambridge.

[10] Bernanke, B., Gertler, M., Gilchrist, S. (1999) The Financial Accelerator in a Quantitative Business Cycle Framework. In: Taylor, J.B. and Woodford, M., Eds., Handbook of Macroeconomics, Elsevier, Amsterdam, 1341-1393.

[11] Kocherlakota, N.R. (2000) Creating Business Cycles through Credit Constraints. Federal Reserve Bank of Minneapolis Quarterly Review, 24, 2-10.

[12] Mittnik, S. and Semmler, W. (2013) The Real Consequences of Financial Stress. Journal of Economic Dynamics and Control, 37, 1479-1499. https://doi.org/10.1016/j.jedc.2013.04.014

[13] Lof, M. and Malinen, T. (2014) Does Sovereign Debt Weaken Economic Growth? A Panel VAR Analysis. Economic Letters, 122, 403-407. https://doi.org/10.1016/j.econlet.2013.12.037

[14] Panizza, U. and Presbitero, A.F. (2014) Public Debt and Economic Growth: Is There a Causal Effect. Journal of Macroeconomics, 41, 21-41. https://doi.org/10.1016/j.jmacro.2014.03.009

[15] Checherita-Westphal, C., Hughes Hallett, A. and Rother, P. (2014) Fiscal Sustainability Using Growth-Maximizing Debt Targets. Applied Economics, 46, 638-647. https://doi.org/10.1080/00036846.2013.861590

[16] Erdil, E. and Yetkiner, I.H. (2009) The Granger-Causality between Health Care Ex- 
penditure and Output: A Panel Data Approach. Applied Economics, 41, 511-518. https://doi.org/10.1080/00036840601019083

[17] Cebula, R.J. (2014) Impact of Federal Government Budget Deficits on the Longer-Term Real Interest Rate in the U.S.: Evidence Using Annual and Quarterly Data, 1960-2013. Applied Economics Quarterly, 60, 23-40. https://doi.org/10.3790/aeq.60.1.23

[18] Puente-Ajovín, M. and Sanso-Navarro, M. (2015) Granger Causality between Debt and Growth: Evidence from OECD Countries. International Review of Economics \& Finance, 35, 66-77. https://doi.org/10.1016/j.iref.2014.09.007

[19] Adrian, T., Moench, E. and Shin, H.S. (2010) Macro Risk Premium and Intermediary Balance Sheet Quantities. IMF Economic Review, 58, 179-207. https://doi.org/10.1057/imfer.2010.5

[20] Gorton, G.B. (2010) Slapped by the Invisible Hand: The Panic of 2007. Oxford University Press, Oxford.

[21] Brunnermeier, M.K. and Sannikov, Y. (2014) A Macroeconomic Model with a Financial Sector. American Economic Review, 104, 379-421. https://doi.org/10.1257/aer.104.2.379

[22] Proaño, C.R., Schoder, C. and Semmler, W. (2014) Financial Stress, Sovereign Debt and Economic Activity in Industrialized Countries: Evidence from Dynamic Threshold Regressions. Journal of International Money and Finance, 45, 17-37. https://doi.org/10.1016/j.jimonfin.2014.02.005

[23] Schleer, F. and Semmler, W. (2013) Financial Sector-Output Dynamics in the Euro Area: Non-Linearities Reconsidered. ZEW Discussion Paper No. 13-068. https://doi.org/10.2139/ssrn.2333592

[24] Hubrich, K. and Tetlow, R.J. (2015) Financial Stress and Economic Dynamics: The Transmission of Crises. Journal of Monetary Economics, 70, 100-115. https://doi.org/10.1016/j.jmoneco.2014.09.005

[25] Van Roye, B. (2014) Financial Stress and Economic Activity in Germany. Empirica, 41, 101-126. https://doi.org/10.1007/s10663-013-9224-0

[26] Hollo, D., Kremer, M. and Lo Duca, M. (2012) CISS-A Composite Indicator of Systemic Stress in the Financial System. Working Paper No. 1426, European Central Bank.

[27] Davig, T. and Hakkio, C. (2010) What Is the Effect of Financial Stress on Economic Activity? Economic Review, 95, 5-62.

[28] Hennessy, C.A., Levy, A. and Whited, T.M. (2007) Testing Q Theory with Financing Frictions. Journal of Financial Economics, 83, 691-717. https://doi.org/10.1016/j.jfineco.2005.12.008

[29] Fouquau, J., Hurlin, C. and Rabaud, I. (2008) The Feldstein-Horioka Puzzle: A Panel Smooth Transition Regression Approach. Economic Modelling, 25, 284-299. https://doi.org/10.1016/j.econmod.2007.06.008

[30] Hakkio, C.S. and Keeton, W.R. (2009) Financial Stress: What Is It, How Can It Be Measured and Why Does It Matter. Economic Review, 2, 50-50.

[31] González, A., Teräsvirta, T. and Dijk, D. (2005) Panel Smooth Transition Regression Models. SSE/EFI Working Paper Series in Economics and Finance.

[32] Kremer, S., Bick, A. and Nautz, D. (2013) Inflation and Growth: New Evidence from a Dynamic Panel Threshold Analysis, Empirical Economics, 4, 861-878. https://doi.org/10.1007/s00181-012-0553-9

[33] Caner, M. and Hansen, B.E. (2004) Instrumental Variable Estimation of a Threshold Model. Econometric Theory, 20, 813-843. 
https://doi.org/10.1017/S0266466604205011

[34] Arellano, M. and Bover, O. (1995) Another Look at the Instrumental Variable Estimation of Error-Components Models. Journal of Econometrics, 68, 29-51.

https://doi.org/10.1016/0304-4076(94)01642-D

[35] Fazzari, S., Ferri, P.E. and Greenberg, E. (2008) Cash Flow, Investment, and KeynesMinsky Cycles. Journal of Economic Behavoir and Organization, 65, 555-572.

https://doi.org/10.1016/j.jebo.2005.11.007 